\title{
APUD cells and neuroepithelial bodies in hamster lung: methods, quantitation, and response to injury
}

\author{
JOHN R PALISANO, AND JEROME KLEINERMAN
}

From the Departments of Pathology and Pathology Research, St Luke's Hospital, Case Western Reserve University, Cleveland, Ohio, and Mount Sinai School of Medicine of the City of New York, USA

ABSTRACT A comparative study of the Falck-Hillarp Technique, a modification of Eaton-Fedde procedure and silver staining of aldehyde-fixed tissue was carried out to determine the most efficient procedure to demonstrate neuroendocrine cells of the hamster and rat lung. The modified EatonFedde procedure is the most efficient method of observing these cells, and is also the easiest to perform. With this method, the normal hamster lung contains a total of $2.00 \times 10^{-1}$ to $3.00 \times 10^{-1}$ neuroendocrine cells $/ \mathrm{mm}$ in the small and large bronchioles. In the larger airways approximately $3 \cdot 51 \times 10^{-1}$ neuroepithelial bodies (NEB)/mm are observed. Immediately after 24-hour exposure to $\mathrm{NO}_{2}$ the number of APUD cells dropped to approximately $25 \%$ of the control levels. These cells were decreased to $50 \%$ of the control levels throughout the 28 days of exposure. The number of NEB decreased transiently after 24 hours of $\mathrm{NO}_{2}$ but returned to normal numbers by day 14 . We recommend the application of fluorescence techniques coupled with standardised sections and quantitative methods of study for analysis of APUD cells and NEB.

In 1949, Frohlich ${ }^{1}$ described a unique cell type in the lung epithelium which had clear cytoplasm and was given the descriptive name Helle-Zellen. Frohlich's observation was subsequently confirmed by Feyrter. ${ }^{2}$ Both investigators used silver impregnation to demonstrate these cells. Feyrter recognised that these cells were part of a diffuse endocrine system which is scattered throughout the epithelium of many organs. In recent years Pearse $^{3}$ has defined these cells on the basis of discrete biochemical characteristics. $\mathrm{He}$ has called them amine precursor uptake and decarboxylation (APUD) cells because of their ability for uptake and decarboxylation of amines. Like APUD cells in other organs these lung epithelial cells are presumed to originate from the neural crest and are believed to secrete polypeptide hormones. $^{34}$ Very recently, Lauweryns and Goddeeris ${ }^{5}$ have described an organoid cluster of cells which contain neurosecretory granules and have neural attachments. These have been called neuroepithelial bodies (NEB). They differ from APUD cells in that the latter are isolated, single cells to which no neural attachment has been regularly observed. Advances in this field have

\footnotetext{
Address for reprint requests: Dr Jerome Kleinerman, Department of Pathology, Mount Sinai School of Medicine, One Gustave L Levy Place, New York, New York 10029, USA.
}

been slow ${ }^{6-10}$ because of the paucity of APUD cells and NEB and difficulty of identifying them. The development and application of the FalckHillarp technique ${ }^{11}$ for the identification APUD cells has initiated renewed interest in these structures which, because of their presumed origin from neural anlage and their specialised secretory function, have also been termed neuroendocrine structures or cells. Several different techniques exist for identifying these cells and it is not clear as to which of these techniques is most specific or sensitive. An ideal technique should meet the following criteria: (1) simplicity, (2) speed, (3) reproducibility, (4) reliability so as to permit quantitation, (5) maintenance of the biochemical moieties within the cells to permit additional chemical characterisation, and (6) the ability to use at least two methods on the same tissue sample for confirmation. With these criteria in mind, we evaluated several methods which demonstrate APUD cells and NEB at the light microscopic level in the tracheobronchial tree and lung. The classical Falck-Hillarp fluorescence procedure using freeze-dried tissue was compared to the EatonFedde technique ${ }^{12}$ which uses frozen sections. These fluorescent techniques were compared to argyrophilic stain procedures using freeze-dried 
tissues and tissues fixed in formalin, glutaraldehyde, or Bouin's fixative. Quantitative methods to evaluate the number of NEB and APUD cells were developed, and the effects of short-term exposures to $30 \mathrm{ppm}$ of $\mathrm{NO}_{2}$ on the number of these neuroendocrine structures were evaluated.

\section{Methods}

Golden Syrian male hamsters, 4-5 months old, weighing 80-100 gm, were used. The animals were fed and watered ad libitum. All animals were primed with $100 \mathrm{mg} / \mathrm{kg}$ body weight of 5-hydroxytryptophan (5-HTP) and L- $\beta$-3-4-dihydroxyphenylalanine (L-DOPA) 30-60 minutes before killing. ${ }^{13}$ Animals were anaesthetised with Nembutal ( $8 \mathrm{mg} / 100 \mathrm{gm}$ body weight) intraperitoneally (IP) and then exsanguinated under anaesthesia by cutting the descending aorta.

\section{FALCK-HILLARP TECHNIQUE}

The lungs were removed immediately after death and inflated with air by means of an intratracheal cannula attached to a syringe. After inflation with approximately $5 \mathrm{cc}$ of air, the trachea was tied and the lungs submerged in liquid nitrogen. The lungs were then transferred to a freeze-drier (Virtis, model number 10-800) and processed over the next two weeks. Upon completion of the drying of the lungs they were removed from the freeze-drier, sliced with a clean razor blade into $2 \mathrm{~mm}$ thick slices, and placed in an oven at $70^{\circ} \mathrm{C}$ for two hours over approximately $5 \mathrm{gm}$ paraformaldehyde. The paraformaldehyde was equilibrated over $\mathrm{H}_{2} \mathrm{SO}_{4}$ in an atmosphere of $50 \%$ relative humidity. ${ }^{14} 15$ The lungs were then placed in paraffin in vacuo for 10 minutes and embedded, the sections cut at $5 \mu \mathrm{m}$ and mounted in Entellan. Fluorescence microscopy was performed on an A/O series 10 Microstar microscope with an epifluorescent unit using a 100 watt halogen lamp and exciter filters BG-12 and KV-418 and barrier filter OG-515. Successive sections of the block were stained by routine haematoxylin and eosin $(\mathrm{H} \text { and } \mathrm{E})^{\mathbf{1 5}}$ and silver stain. ${ }^{17}$

\section{MODIFIED EATON-FEDDE TECHNIQUE}

Immediately after death, the animal's lungs and trachea were removed in toto and the lungs distended via a tracheal cannula with a $2: 1$ solution of phosphate-buffered paraformaldehyde ${ }^{12}$ and OCT embedding medium (Lab-Tek Products). The lung was immediately cut coronally, both ventrally and dorsally to the trachea with a clean razor blade. A $5-8 \mathrm{~mm}$ slice with trachea removed was taken from the midportion of the lung. The sections were submerged directly intef liquid nitrogen where they remained until placeof in the freeze-drier (Virtis, model number 10-800) Subsequent processing of the tissue was identicab to that described for the Falck-Hillarp method ology.

\section{SILVER METHOD}

Identification of APUD cells and NEB by silvew staining methods was attempted on Bouin's-fixed $\vec{\nabla}$ formaldehyde-fixed, glutaraldehyde-fixed, and freeze-dried tissue in hamster and Bouin's-fixedr and freeze-dried tissue in rabbit. The intestine and lung from the same animals were stained simultaneously by Pascual's, ${ }^{17}$ Grimelius, ${ }^{18}$ andb Siever-Munger's ${ }^{19}$ silver stains. Pascual's silver. stain was adopted because it proved to be the fastest, easiest, and most reproducible method Pascual's silver stain was carried out in the fol lowing way. Slides were deparaffinised in xylen $\infty$ and then run down through a graded alcohoP series to a distilled water rinse. They were therb placed in a $0.5 \%$ aqueous silver nitrate solution for two hours at $60^{\circ} \mathrm{C}$. After two hours the slideso were rinsed in two distilled water rinses andहै placed in a reducing solution $(5 \mathrm{gm}$ of sodium $\mathbb{D}$ sulphite and $1 \mathrm{gm}$ hydroquinone $/ 100 \mathrm{ml} \mathrm{H}_{2} 0$ ) for 10 minutes at $60^{\circ} \mathrm{C}$. The slides were then rinsed in running tap water and distilled water for three? minutes. If necessary the slides can be reimpreg? nanted in a fresh silver solution at $60^{\circ} \mathrm{C}$ for $10=$ minutes and reduced again as described above.

\section{QUANTITATION}

Quantitation of APUD cells and NEB was car ried out on silver-stained sections or on unstained sections prepared for fluorescent microscopic study as described above. Either standard mid윽 coronal sections of both lungs or randomlys selected sections of peripheral lungs were used?을 The smallest transverse diameter of all airways was measured with a calibrated eyepiece micrometer on every slide studied and airwayso separated into three categories on the basis of their diameter: (1) 0.01 to $0.19 \mathrm{~mm}$ diametero (2) $0.20 \mathrm{~mm}$ and greater but without cartilage ino the wall, and (3) bronchi. These categories of airway size were selected arbitrarily after pre? liminary studies indicated that the separation intor a greater number of size classes did not change? the analysis or interpretation significantly. Tra $\mathbb{D}$ cheas were not studied because of technica依 difficulties. All airways and alveolar ducts in the standard midcoronal sections or random peripheral sections were studied and the number of 
APUD cells and NEB in each airway category were noted separately. The circumference of each airway was measured using a calibrated eyepiece micrometer. The total number of APUD cells and NEB were each noted separately and described per total $\mathrm{mm}$ of airway circumference. These ratios of NEB $/ \mathrm{mm}$ and APUD cells $/ \mathrm{mm}$ were summated for all airways in each size category. For example, if there were 10 APUD cells in a total of $52.8 \mathrm{~mm}$ of airways with diameters of $0.01-0.19 \mathrm{~mm}$, then the ratio was $10 / 52.8$ or $19.5 \times 10^{-2}$ APUD cells per mm of airway. Many airways contained no APUD cells or NEB; for this reason the values are described for the total number of APUD cells or NEB in the total length of airways ( $\mathrm{mm}$ ) for each tissue section and each slide can be described by only one ratio value of

$$
\frac{\text { total APUD }}{\text { total } \mathrm{mm}} \text { or } \frac{\text { total NEB }}{\text { total } \mathrm{mm}}
$$

This value is then reduced to APUD/mm or $\mathrm{NEB} / \mathrm{mm}$ for each order of airway for each slide in the group studied. Because of this limitation each order of airway can be expressed as only one value, without standard deviation or standard error even though the results expressed are mean values.

\section{$\mathrm{NO}_{2}$ EXPOSURES}

Hamsters were exposed 24 hours per day to $30-40$ ppm of $\mathrm{NO}_{2}$ for one day, 14 days, and 28 days as previously described by Kleinerman and Rynbrandt. ${ }^{20}$ While in the exposure chambers the animals were fed four food pellets a day and watered ad libitum. Half an hour before the animals were to be killed they were primed (as described earlier) and returned to the $\mathrm{NO}_{2}$ chamber. At the scheduled time the animals were quickly removed from the $\mathrm{NO}_{2}$ chamber, killed and the lungs processed and quantitated as described for the control animals.

\section{Results}

\section{FALCK-HILLARP TECHNIQUE}

On close observation, freeze-dried tissue reveals a good state of preservation in most areas. A prominent characteristic of freeze-dried tissue is the vacuolated appearance of cytoplasm caused by ice crystal formation (fig 1). Although the epithelium of the airways is rarely compressed, the cilia almost always are. Secretory activity is never observed in the Clara or goblet cells (figs 1 and 2). Desquamated cells on the surface are

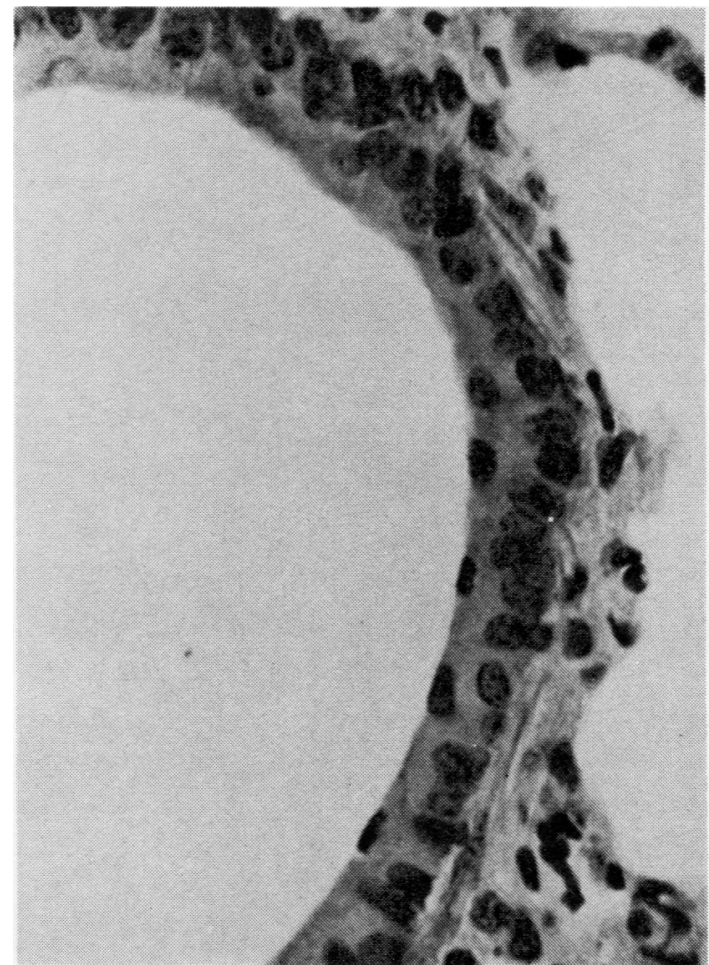

Fig 1 Hamster airway epithelium in a small bronchiole using the Falck-Hillarp technique. ( $H$ and $E$, original magnification $\times 2800)$.

preserved in situ by contrast with other methods of fixation. With this procedure one obtains brightly fluorescent APUD cells and NEB as well as mast cells. Positive argyrophilia can be demonstrated in these cells using either the Grimelius or Pascual silver staining methods in both rabbit and hamster intestine and lung. The major drawbacks of this procedure are the amount of time it takes to process the tissue (approximately two weeks in the freeze-drier) and the fact that it is difficult to achieve standard sections of lung from animal to animal to carry out the quantitative studies.

\section{MODIFIED EATON-FEDDE TECHNIQUE}

The bronchiolar epithelium and lung tissue appear to be better preserved by using this technique rather than the Falck-Hillarp procedure. Although few of the epithelial cells are compressed using the Falck-Hilarp technique, care must be taken not to compress the epithelial cells by overdistension of the lung with the fixative (fig 1). The secretory activity which is a prominent feature of the epithelium in routine 


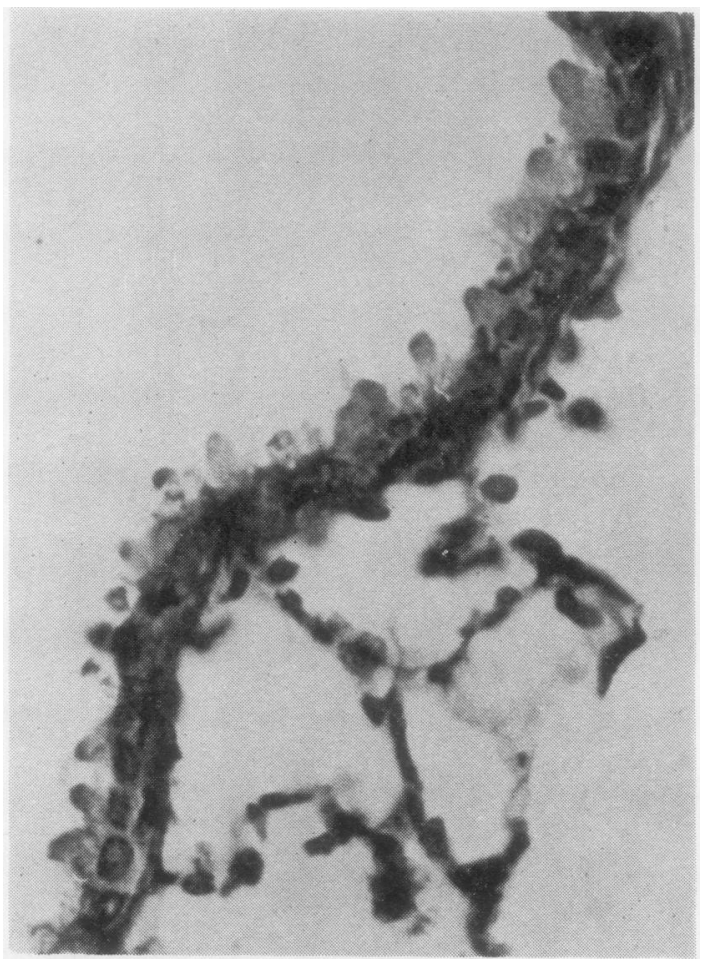

Fig 2 Hamster bronchiole epithelium and lung using the modified Eaton-Fedde technique. Notice that the secretory activity of the epithelium is preserved and that the cilia are not matted. $(H$ and $E$, original magnification $\times 2800)$.

histology is preserved with the Eaton-Fedde technique (fig 2). If the lung is carefully distended, tufts or cilia are prominent features in the airway lumens. Positive fluorescence of the APUD cells and NEB is easily demonstrated by this technique and the cells appear to fluoresce more brightly than with the Falck-Hillarp procedure (fig 3). Although we have been unable to demonstrate positive argyrophilia of APUD cells in the lung by either the Grimelius or Pascual silver stains, we have demonstrated positive argyrophilia in other aldehyde tissues (such as stomach and intestine) in the same animals from which the lungs were obtained. It is, however, much easier to obtain standardised sections with this procedure.

\section{SILVER STAINS}

Paraffin-embedded freeze-dried tissue stained reliably with all argyrophil stains. Bouin's and aldehyde-fixed lung tissue did not accept these stains even though intestinal tissue fixed and processed in the same batch as lung accepted the

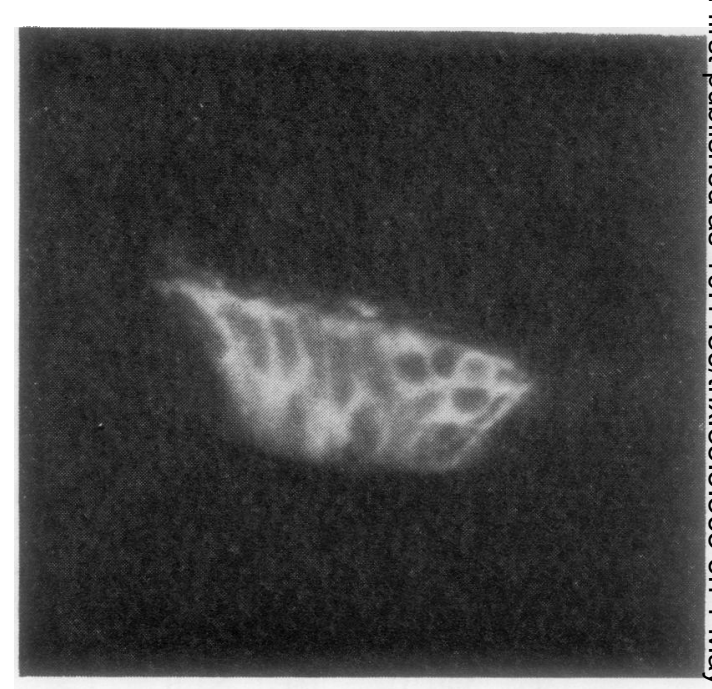

(a)

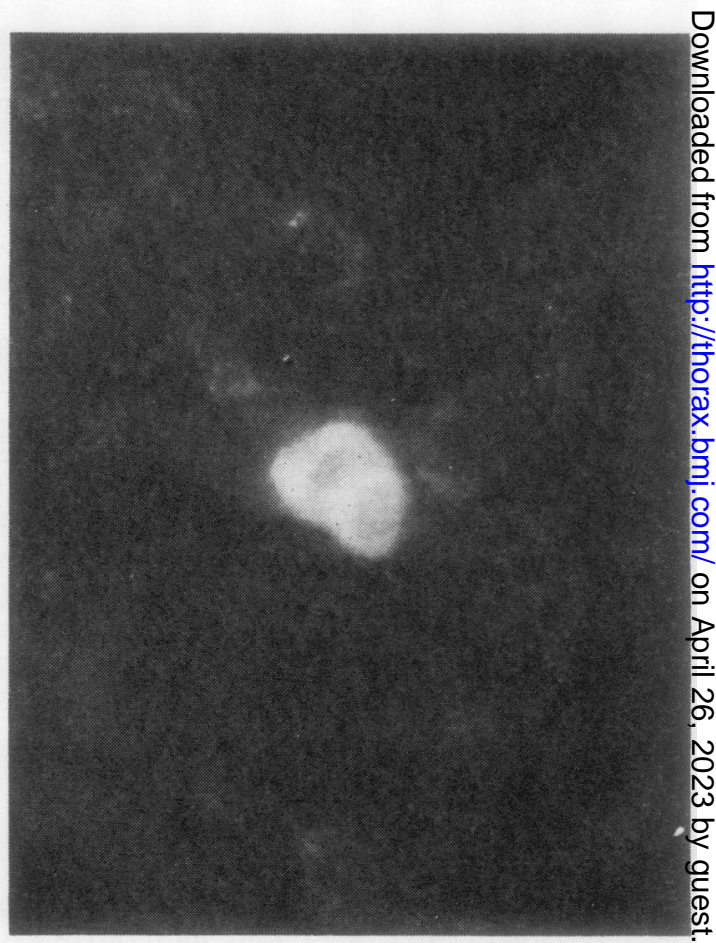

(b)

Fig 3 Fluorescence microscopy of a neuroepithelial body in hamster airway (a) and lung (b) demonstrated by the modified Eaton-Fedde technique. Original magnification $\times 3000$ (a) and $3700(b)$. 
argyrophil stain with reliability. The reason for the inability to stain lung tissue treated with Bouin's or aldehyde fixation is not clear. Rabbit lung, however, fixed with aldehyde fixatives stained positively with the indicated silver stains.

\section{QUANTITATION}

The number of APUD cells and NEB per mm of airways detected by fluorescence was compared with those detected by silver stains. In this study fluorescent sections and silver-stained sections were from the same freeze-dried, randomly selected peripheral blocks of lungs. The values are listed in table 1 . These data suggest that greater numbers of APUD cells and NEB are consistently detected by fluorescence emission than by silver staining. These were found in spite of the greater length of small airway surface for study in the silver stain group.

To minimise further variability associated with random selections of blocks of tissue, these structures were quantitated in a standardised midcoronal section by fluorescence emission from freeze-dried paraffin-embedded sections. Sections were cut from the same block at $100 \mu \mathrm{m}$ intervals, and the number of APUD cells and NEB in the airways of various sizes counted in relation to the total airway surface for each order of bronchus or bronchiole. The number of NEB in the bronchioles was relatively constant through a distance of $500 \mu \mathrm{m}$ (six sections); the APUD cells, however, were constant for only $100 \mu \mathrm{m}$ depth (two sections) and their number decreased prominently in deeper sections (table 2). There were constant numbers of $0.2-0.24 \times 10^{-1}$ APUD cells $/ \mathrm{mm}$ in the bronchioles and $0.31 \times 10^{-1}$ in bronchi. Neuroepithlial bodies were present in similar numbers; in the small bronchioles they numbered $0.19 \times 10^{-1}$; in larger bronchioles $0.28 \times 10^{-1}$, and in the bronchi $0 \cdot 18 \times 10^{-1}$ per $\mathrm{mm}$. The values for APUD cells were considerably greater than those in randomly selected peripheral sections in air-

Table 1 APUD cells and NEB in random section of peripheral hamster lung identified by

fluorescence $(n=2)$ and by silver stain $(n=3)$

\begin{tabular}{lccl}
\hline Airway diameter & $\begin{array}{l}\text { Total mm } \\
\text { airway }\end{array}$ & NEB/mm & APUD $/ \mathrm{mm}$ \\
\hline Fluorescence & & & \\
$0.01>0.19$ & 207.72 & $1.39 \times 10^{-1}$ & $0.28 \times 10^{-1}$ \\
$0.20>$ & 171.05 & $1.46 \times 10^{-1}$ & $1.11 \times 10^{-1}$ \\
Bronchi & 34.32 & $0.87 \times 10^{-1}$ & 0 \\
Silver Stain & & $0.75 \times 10^{-1}$ & $0.08 \times 10^{-1}$ \\
$0.01>0.19$ & 213.2 & $1.29 \times 10^{-1}$ & $0.42 \times 10^{-1}$ \\
$0.20>$ & 359.6 & $0.33 \times 10^{-1}$ & 0 \\
Bronchi & 30.1 & & \\
\hline
\end{tabular}

ways of all sizes (compare tables 1 (top section) and 2). More NEB were also detected in standard midcoronal sections as compared with the values in the peripheral sections.

Table 3 contains data for $\mathrm{NO}_{2}$ exposed animals. Coronal sections were cut from two animals for each exposure period and epithelial surfaces measured. Although there was considerable variation in the amount of epithelial surface available for study, the number of NEB/mm of small and large bronchioles was similar in the controls and the animals exposed to $\mathrm{NO}_{2}$ for one, 14 , and 28 days. This was not true for the bronchi, which reflected a marked decrease in NEB after 24 hours of $\mathrm{NO}_{2}$ exposure with increase of NEB on day 28 to approximately half the values present in control hamsters. On the other hand, the number or density of APUD cells decreased markedly within the first day of exposure to $\mathrm{NO}_{2}$. In the small and large bronchioles the number of APUD cells/mm increased by day 14 of exposure and remained at this level for the entire 28 days of exposure.

In order to compare better our values with those previously reported by Moosavi et $a,^{8}$ a

Table 2 APUD cells and NEB at different depths in airways

\begin{tabular}{|c|c|c|c|c|}
\hline $\begin{array}{l}\text { Depth } \\
\text { section cut } \\
(\mu \mathrm{m})\end{array}$ & $\begin{array}{l}\text { Airway } \\
\text { diameter }\end{array}$ & $\begin{array}{l}\text { Total } \mathrm{mm} \\
\text { airway }\end{array}$ & $N E B / m m$ & $A P U D / \mathrm{mm}$ \\
\hline 0 & $\begin{array}{l}<0.2 \\
>2 \\
\text { Bronchi }\end{array}$ & $\begin{array}{r}115 \cdot 7 \\
117 \cdot 4 \\
74 \cdot 1\end{array}$ & $\begin{array}{l}1.46 \times 10^{-1} \\
1.80 \times 10^{-1} \\
2.83 \times 10^{-1}\end{array}$ & $\begin{array}{l}1.72 \times 10^{-1} \\
2.70 \times 10^{-1} \\
3.77 \times 10^{-1}\end{array}$ \\
\hline 100 & $\begin{array}{l}<0.2 \\
>0.2 \\
\text { Bronchi }\end{array}$ & $\begin{array}{r}92 \cdot 9 \\
160 \cdot 4 \\
37 \cdot 0\end{array}$ & $\begin{array}{l}2.26 \times 10^{-1} \\
3.86 \times 10^{-1} \\
0.81 \times 10^{-1}\end{array}$ & $\begin{array}{l}2.36 \times 10^{-1} \\
2.05 \times 10^{-1} \\
2.43 \times 10^{-1}\end{array}$ \\
\hline 200 & $\begin{array}{l}<0.2 \\
>0.2 \\
\text { Bronchi }\end{array}$ & $\begin{array}{l}39 \cdot 5 \\
74 \cdot 2 \\
-\end{array}$ & $\begin{array}{l}2.52 \times 10^{-1} \\
1.88 \times 10^{-1} \\
-\end{array}$ & $\begin{array}{l}0.75 \times 10^{-1} \\
0.94 \times 10^{-1}\end{array}$ \\
\hline 300 & $\begin{array}{l}<0.2 \\
>0.2\end{array}$ & $\begin{array}{l}24 \cdot 3 \\
26 \cdot 7\end{array}$ & $\begin{array}{l}2.47 \times 10^{-1} \\
1.87 \times 10^{-1}\end{array}$ & - \\
\hline 400 & $\begin{array}{l}<0.2 \\
>0.2\end{array}$ & $\begin{array}{l}41 \cdot 4 \\
67 \cdot 5\end{array}$ & $\begin{array}{l}1.44 \times 10^{-1} \\
1.18 \times 10^{-1}\end{array}$ & $\begin{array}{l}0.48 \times 10^{-1} \\
0.14 \times 10^{-1}\end{array}$ \\
\hline 500 & $\begin{array}{l}<0.2 \\
>0.2\end{array}$ & $\begin{array}{l}21 \cdot 4 \\
20 \cdot 7\end{array}$ & $\begin{array}{l}1.38 \times 10^{-1} \\
2.40 \times 10^{-1}\end{array}$ & $0.46 \times 10^{-1}$ \\
\hline
\end{tabular}

Table 3 Effect of $\mathrm{NO}_{2}$ on APUD cells and NEB by fluorescence

\begin{tabular}{lllll}
\hline & $\begin{array}{l}\text { Airway } \\
\text { diameter }\end{array}$ & $\begin{array}{l}\text { Total mm } \\
\text { airway }\end{array}$ & NEB/mm & APUD/mm \\
\hline Control & $<0.2$ & 532.7 & $2.94 \times 10^{-1}$ & $2.20 \times 10^{-1}$ \\
$(\mathbf{n}=3)$ & $>0.2$ & 693.3 & $2.37 \times 10^{-1}$ & $2.19 \times 10^{-1}$ \\
& Bronchus & 111.1 & $2.33 \times 10^{-1}$ & $3.51 \times 10^{-1}$ \\
1 day & $<0.2$ & 73.8 & $2.20 \times 10^{-1}$ & $0.73 \times 10^{-1}$ \\
$(\mathbf{n}=2)$ & $>0.2$ & 160.6 & $2.07 \times 10^{-1}$ & $1.05 \times 10^{-1}$ \\
& Bronchus & 33.9 & $0.45 \times 10^{-1}$ & - \\
14 day & $<0.2$ & 49.0 & $3.76 \times 10^{-1}$ & $1.50 \times 10^{-1}$ \\
& $>0.2$ & 187.1 & $2.68 \times 10^{-1}$ & $1.33 \times 10^{-1}$ \\
& Bronchus & - & 2.3 & - \\
28 day & $<0.2$ & 203.0 & $2.33 \times 10^{-1}$ & $1.12 \times 10^{-1}$ \\
& $>0.2$ & 233.2 & $2.23 \times 10^{-1}$ & $1.50 \times 10^{-1}$ \\
& Bronchus & 58.6 & $1.35 \times 10^{-1}$ & $2.38 \times 10^{-1}$ \\
\hline
\end{tabular}


quantitative study of neuroendocrine cells was performed in neonatal rats. The data in table 4 indicate that the frequency of APUD cells and NEB was similar in small and large bronchioles. However, the total number of neuroendocrine cells in the neonatal rat was substantially less than the number observed in adult hamster, and considerably less than the number reported in this species by other investigators.

\section{Discussion}

\section{FALCK-HILLARP TECHNIQUE}

Although the preservation by this freeze-drying method is not comparable to standard aldehyde fixation, the tissue is acceptable for light and fluorescent microscopic study. The cytoplasm of cells is generally vacuolated, many ciliated cells have lost their cilia, and some cells are disrupted. APUD cells and NEB are easily distinguished from all other epithelial cell types in fluorescent sections and silver-stained sections. There are several disadvantages in the use of this technique. These include the need for specialised equipment such as the freeze-dry apparatus and fluorescent microscope, and the difficulties associated with obtaining a standard section for study, which is both properly fixed in inflation and processed with adequate rapidity to preserve the intracellular materials. Furthermore, tissue preserved by the freeze-dry method is not suitable for electron microscopy because of its poor state of preservation.

\section{EATON-FEDDE TECHNIQUE}

As with the Falck-Hillarp technique, it is easy to distinguish the brightly fluorescent APUD cells and NEB from other fluorescent cells such as mast cells and macrophages. The enhanced fluorescence that one obtains after this modification of the Eaton-Fedde technique is probably a result of the concentration of the secretory products during the sublimation process. The advantages of the modified Eaton-Fedde technique is the ability to prepare standard sections of lung before they are frozen in liquid nitrogen. The viscous OCT solution with which the lung is distended gives structural support so that uniform coronal sections can be cut from the lung. This proce-

Table 4 APUD cells and NEB in four neonatal rats

\begin{tabular}{llll}
\hline Airway diameter & $\begin{array}{l}\text { Total mm } \\
\text { airway }\end{array}$ & NEB/mm & APUD $/ \mathrm{mm}$ \\
\hline$<0.2$ & 102.9 & $0.48 \times 10^{-1}$ & $0.87 \times 10^{-1}$ \\
$>0.2$ & 32.9 & $0.30 \times 10^{-1}$ & $0.91 \times 10^{-1}$ \\
Bronchi & 3.2 & - & - \\
\hline
\end{tabular}

dure like the classical Falck-Hillarp technique has $\overrightarrow{\vec{F}}$ several disadvantages. There is a delay of up to 0 two weeks during the tissue processing but the consistency and reliability of the fluorescent structures is excellent. The Eaton-Fedde tech- $\mathbb{\Phi}$ nique as modified in this study is simple, reproducible, and consistent. A major problem using ${ }^{\mathcal{S}}$ this method is our inability to obtain silver stain-. ing of APUD cells or NEB in the hamster $\overrightarrow{-}$ tracheobronchial tree and lung, whereas the Falck-Hillarp procedure stains APUD cells and NEB reliably with silver stains.

\section{QUANTITATION}

The comparison of fluorescence and silver stain methods for detecting neuroendocrine structureso from randomly selected blocks of peripheral lung tissue (table 1) indicates the greater sensitivitys and reliability of the fluorescence methods. This analysis was performed on successive sectionsfrom the same tissue block. The method ofo expressing numerical values for NEB and APUD cells permits only a single mean value for each animal in spite of the large amount of airways surface studied per animal. These circumstanceso do not permit valid application of the commoñ statistical methods of analyses of data. However, the consistently larger values for APUD cells and NEB in the fluorescent preparations strongly sug 3 gest it as the method of choice for detection of neuroendocrine structures.

Quantitative studies indicate that normal male hamsters contain $1.72-3.77 \times 10^{-1}$ APUD cells $\mathrm{mm}$ and between $1.46-2.83 \times 10^{-1} \mathrm{NEB} / \mathrm{mm}$ iñ the small airways and bronchioles of the lungo The number of APUD cells and NEB $/ \mathrm{mm}$ of the bronchus in control animals is greater than in the small airways. The reason for this virtual doub ling of APUD cells and NEB in the large airways is not known but may reflect the need foD specialised responses in epithelium of the large. airways for control of ciliary motility, goblet certy secretion, or epithelial permeability. APUD cells are not present in constant numbers in succeso sive sections taken at $100 \mu \mathrm{m}$ intervals from the standard tissue block; however, NEB are con sistently present to a depth of $600 \mu \mathrm{m}$. These dife ferences are believed to result from inadequat $\bar{\oplus}$ exposure to and reaction with formaldehyde $\mathbb{e}^{+}$ vapours of the APUD cells in deeper portions of the tissue block. The numbers of APUD cell and NEB in the random sections of periphera lung are also less than those observed in standar midcoronal blocks. This may reflect a true differ ence in distribution of the neuroendocrine struc tures favouring a greater number in the centrag 
airways. Additional studies are needed to confirm this observation.

In studies of the effect of exposure to $\mathrm{NO}_{2}$ the number of APUD cells is profoundly depressed after 24 hours of exposure, but the number and distribution of NEB is not altered. The decrease in APUD cells persists for the entire 28-day exposure period as compared with control values, but is greater at seven and 14 days than at day 1 of $\mathrm{NO}_{2}$. Neuroepithelial bodies are not significantly altered in the small airways, but a decrease in number in the large airways persists at 28 days of exposure as compared with controls. $\mathrm{NO}_{2}$ is a powerful oxidising agent producing cellular changes which vary with the concentration and duration of exposure. Our data suggest that the APUD cells are responsive to $\mathrm{NO}_{2}$ exposure, possibly by degranulation or desquamation resulting from acute APUD cell stimulation. This response is not observed in the NEB, perhaps because of the greater mass of these structures. APUD cells occur singly while NEB represent a cluster of neuroendocrine cells. It is possible that some cells of the NEB retain their granules after $\mathrm{NO}_{2}$ exposure which may have responded by fluorescence and are more easily detected than individual APUD cells. Additional electron microscopic study is required to evaluate this hypothesis that degranulation of APUD cells does inded occur after exposure to $\mathrm{NO}_{2}$.

Three studies have been reported in which quantitative values of the neurosecretory cells have been performed. Tateishi ${ }^{21}$ found between $19-41 \%$ of the human lungs examined contained argyrophilic cells in various airways from segmental bronchi to bronchioles, while only 1-9\% of the lungs had argyrophilic cells in larger bronchi and terminal bronchioles. These data are difficult to compare with ours because Tateishi made no attempt to quantitate the APUD cells or NEB, nor to differentiate these two types of neuroendocrine structures.

Moosavi $e t a l^{8}$ quantitated the number of Feyrter cells $/ \mathrm{cm}$ in bronchial epithelium of 4 to 31-day-old rats and observed that the cells increase from $32-59 / \mathrm{cm}$ to $70 / \mathrm{cm}$ between day 4 and day 7 of life and decrease to $16 / \mathrm{cm}$ by day 31. These data indicate that neonatal and young rats may have 10-60 times the number of similar cells which we observed in adult hamsters. This discrepancy may be in part the result of species and age differences. However, the studies performed by us on young rats indicate that species difference is not significant. In our study, 3-dayold rats had $0.48 \times 10^{-1}$ to $0.77 \times 10^{-1}$ neuroendocrine cells $/ \mathrm{mm}$ in airways up to $0.2 \mathrm{~mm}$ and
0.30 to $2.91 \times 10^{-1}$ cells $/ \mathrm{mm}$ in larger airways. These values are only slightly less than our values for adult hamsters, but one-tenth the number reported in rats by Moosavi et al, in neonatal rats. In that report ${ }^{8}$ only occasional Feyrter cells were observed in adult rats and clumps of Feyrter cells were "described" in the process of exfoliation. These latter structures may represent what is now characterised as NEB. It is possible that the difference in numbers of APUD cells found in our studies as compared with that of Moosavi et al may be the result of variations in the number of these cells in neonatal, growing and adult animals. Moosavi ef $a l^{8}$ and others ${ }^{22-24}$ have demonstrated that degranulation of the APUD cells and NEB occur in rabbits subjected to hypoxic conditions. Exposure to $30-40 \mathrm{ppm}$ of $\mathrm{NO}_{2}$ may lead to hypoxia as a result of pulmonary oedema after 12-48 hours. However $\mathrm{NO}_{2}$ may injure the cell membrane because of its oxidative potential and produce an exocytosis of the neurosecretory granules. Taylor ${ }^{24}$ reported an increase in the number of APUD cells in rabbits born and raised in the Andes as compared to rabbits reared in England. Hernandez Vasquez et al, ${ }^{25}$ however, reported that the number of APUD cells in rabbits decreases when they are exposed acutely to hypoxia. These observations suggest that adaptation to hypoxia during growth and development may influence the APUD cells in a manner completely different from that in animals not adapted to the hypoxic environment. Degranulation of the APUD cells is reported to occur only as a result of acute hypoxia.

The differences in the quantitative values of APUD cells in our work as compared with that of Moosavi et $a l^{8}$ are difficult to explain. Several differences in technique may have contributed to the discrepancy. Moosavi et al, ${ }^{8}$ Taylor, ${ }^{24}$ and Hernandez-Vasquez $e t a^{25}$ used silver staining of aldehyde-fixed tissue to detect these cells. It is not likely that this difference is the basis of the discrepancies since our studies indicate that fluorescence techniques are more sensitive and reliable than are silver staining methods. Approximately half as many APUD cells and NEB were detected in our silver-stained studies of freezedried lung tissue as by the fluorescence method. Additional studies using acceptable quantitative techniques may provide further information on the role of the APUD cells and NEB in injury and disease states of the lung.

This work was supported in part by a grant from The Council for Tobacco Research, USA, Grant 
number 1190 , and Grant number 1R01HL22202CVA from the National Heart, Lung, and Blood Institute of the National Institutes of Health.

\section{References}

1 Fröhlich F. Die "Helle Zelle" der bronchialscheimhaut and ihre beziehungen zum problem der chemoreceptoren. Frankfurter $Z$ Pathol 1949; 60:517-59.

2 Feyrter F. Zur pathologie des argyrophilen helle-zellen-organes in bronchialbaum des menschen. Virchows Arch 1954; 325:723-32.

3 Pearse AGE. Common cytochemical properties of cells producing polypeptide-hormones, with particular reference to calcitonin and the thyroid C cells. Vet Res 1966; 79:587-90.

4 Pearse AGE, Polak JM. Cytochemical evidence for the neural crest origin of mammalian ultimobranchial omission. Histochemie 1971; 27: 96-102.

5 Lauweryns JM, Goddeeris P. Neuroepithelial bodies in human child and adult lung. Am Rev Respir Dis 1975; 111:469-76.

6 Lauweryns JM, Peuskins JC. Argyrophil (kinin and amine producing?) cells in human infant airway epithelium. Life Sci 1969: 8:577-85.

7 Terzakis JA, Sommors SC, Anderson B. Neurosecretory appearing cells of human segmental bronchi. Lab Invest 1972; 26:127-32.

8 Moosavi H, Smith P, Heath D. The Feyrter cell in hypoxia. Thorax 1973; 28:729-41.

9 Hage E. Histochemistry and fine structure of endocrine cells in foetal lungs of the rabbit, mouse and guinea pig. Cell Tissue Res 1974; 149:513-24.

10 Cutz EW, Chan W, Wong V, Conen PE. Ultrastructure and fluorescence histochemistry of endocrine (APUD-type) cells in tracheal mucosa of human and various animal species. Cell Tissue Res 1975; 158:425-37.

11 Falck B, Hillarp NA, Thieme G, Thorp A. Fluorescence of catecholamines and related compounds condensed with formaldehyde. $J$ Histochem Cytochem 1962; 10:348-54.

12 Eaton JA, Fedde MR. Identification of two populations of biogenic amine-containing cells in the mouse lung. Cell Tissue Res 1977; 176:243-49.
13 Hakanson R, Lilja B, Owman C. Cellular localis- $\vec{\Rightarrow}$ ation of histamine and monoamines in the $\stackrel{\oplus}{+}$ gastric mucosa of man. Histochemie 1969; 18:74-86.

14 Hamberger B, Malmfors T, Sachs C. Standardis- $\frac{\bar{\rho}}{-}$ ation of paraformaldehyde and of certain pro- $\stackrel{\mathbb{Q}}{\circ}$ cedures for the histochemical demonstration of catecholamines. J Histochem Cytochem 1965; ${ }^{\circ}$ 13:147.

15 Corrodi H, Hillarp NA, Jonsson G. Fluorescence methods for the histochemical demonstration of $\vec{\sigma}$ monoamines. 3. Sodium borohydride reduction of the fluorescent compounds as a specificity $\vec{x}$ test. J Histochem Cytochem 1962; 12:582-6. is

16 Gray P. The microtomist's formulary and guide. ir New York: McGraw-Hill, 1954.

17 Pascual JSF. A new method for easy demon- $\mathcal{W}$ stration of argyrophil cells. Stain Technol 1976; 오 51:231-5.

18 Grimelius L. The argyrophil reaction in islet cells of adult human pancreas studied with a new silver nitrate procedure. Acta Soc Med Upsala $\vec{\bullet}$ 1968; 73:271-94.

19 Sevier AC, Munger BL. A silver method for. paraffin sections of neural tissue. $J$ Neuropathol Exp Neurol 1965; 24:130-5.

20 Kleinerman J, Rynbrandt DJ. Lung proteolytic activity and serum protease inhibition after $\mathrm{NO}_{2} \stackrel{2}{2}$ exposure. Arch Environ Health 1976; 31:37-41. $\frac{\mathbb{Q}}{\mathbb{Q}}$

21 Tateishi R. Distribution of argyrophil cells in adult human lungs. Arch Pathol 1973; 96:198-응 202.

22 Lauweryns JM, Peuskins JC, Cokelaere M. Argyrophil, fluorescent and granulated (peptide and amine producing?) AFG cells in human infant bronchial epithelium. Light and electron microscopic studies. Life Sci 1970; 9:1417-29.

23 Lauweryns JM, Cokelaere M, Deleersynder D, Liebens $M$. Intrapulmonary neuroepithelial: bodies in newborn rabbits. Cell Tissue Res 1977; 182:425-40.

24 Taylor W. Pulmonary argyrophil cells at higho altitude. J Pathol 1977; 122:137-44.

25 Hernandez-Vasquez A, Will JA, Quay WB. 음 Quantitative characteristics of the Feyrter (APUD) cells of the neonatal rabbit lung in normoxia and chronic hypoxia. Thorax 1977; 32:449-56. 